\title{
Relevant Local Fatwā on the Issues of Using Human Tissues in Articular Cartilage Tissue Engineering Experimentation
}

\author{
Muhammad Aa'zamuddin $A R^{a}$, Nur Syamimi $M A^{a}$, Abdurezak $A H^{b^{*}}$, Azhim $A^{a}$, Munirah $S^{c}$ \\ ${ }^{a}$ Department of Biomedical Science, Kulliyyah of Allied Health Sciences, International Islamic University Malaysia. \\ ${ }^{b}$ Department of Biotechnology, Kulliyyah of Science, International Islamic University Malaysia. \\ ${ }^{c}$ Department of Physical Rehabilitation Sciences, Kulliyyah of Allied Health Sciences, International Islamic University Malaysia.
}

\begin{abstract}
In articular cartilage tissue engineering (ACTE) experimentation, the researchers have utilised cells and tissues sampled from the human donor for research purposes. The cells and tissues may be harvested from the living donor's discarded tissues through a medical procedure, e.g. the total knee replacement surgery. The small pieces of a tissue sample taken from the human donor are essential to study the articular cartilage regeneration for treating joint disease, i.e. osteoarthritis. However, the procedure has raised some ethical and figh (Islamic jurisprudence) concerns. The study was done by utilising the secondary analysis of local Muslim jurists' opinions (fatwa) related to the sampling of human biological samples. This paper explores the scenarios of using cell sources taken from the living human donor through the existing fatwa of local Muslim jurists (fuqahä). The scenarios include: (1) taking samples from the living donor, and (2) discarding human tissue, as practised in ACTE experimentation. The current fatwa has shown that honouring every part of a human body is considered essential in Islam. ACTE researchers may utilise the biological samples from living donors as alternatives in studying articular cartilage regeneration. The donation of human biological samples for research purposes in ACTE experimentation, obtained from a medical procedure, may be permissible, should the stipulated terms and conditions were observed, and the procedure does not cause any additional harm to the donor.
\end{abstract}

KEYWORDS: Articular cartilage, tissue engineering, experimentation, cell sources, Malaysian fatwā

\section{INTRODUCTION}

The development of scientific knowledge shall be geared to improve the health conditions of society. Perhaps, this is one of the reasons why Muslim jurists had acknowledged the importance of biomedical practices and thus, in principle, agreed on the permissibility of its practices. However, they have also raised some ethical and Islamic jurisprudence $(f i q h)$ concerns about the methods used and the implications of biomedical

Corresponding Author:

Assoc. Prof. Dr. Abdurezak Abdulahi Hashi

Department Of Biotechnology,

Kulliyyah Of Science,

International Islamic University Malaysia,

Jalan Sultan Ahmad Shah, Bandar Indera Mahkota,

25200 Kuantan, Pahang Darul Makmur, Malaysia

Tel No: +609-570 5043

E-mail : hashi@iium.edu.my application. ${ }^{1-5}$ Despite the great discovery of articular cartilage tissue engineering (ACTE) to treat joint diseases, i.e. osteoarthritis, harm, and therapeutic uncertainties spark the ethical concerns that surround the technology, and this includes the research on the technology itself. ${ }^{6}$ Indeed, the ACTE may address the osteoarthritis from five objectives of Islamic law (maqāsid al-shar ${ }^{-} a h$ ), namely, the protection of faith, life, wealth, mind, and offspring. ${ }^{7}$ However, Muslim jurists and ethicists may raise concerns about the permissibility (ibahhah) of the ACTE experimentation before the technology is being extensively applied in Malaysia. The issues include the practice of using and disposing of human samples in researches to develop ACTE. Thus, opinions of local Muslim scholars through fatwa with regards to the experimentation in ACTE were explored. 
Until now, in Malaysia, there is no specific fatwa that has been given on the permissibility of the experimentation of ACTE as the research itself involves a multidisciplinary field with multiple phases and levels from bench to bedside. ${ }^{8}$ The issues of using human biological samples in ACTE experimentation can be divided into different scenarios: (1) taking samples from the dead human body, (2) taking samples from the living donor, (3) transplanting human tissue or cells into animal models, and (4) discarding human tissue as practised in ACTE laboratories. In this paper, the present authors focused on the second and fourth scenarios.

The practices in ACTE experimentation can be considered as new emerging issues in fiqh al-nawäril, a branch of Islamic jurisprudence that addresses contemporary issues. Such matters require fiqh reasoning (ijtihād) based on ușul (principles and precepts of shar $\left.^{-} a b\right)$ due to the lack of textual evidence on the upcoming issue. This ijtibäd is conducted by fuqahä or Muslim jurists who will provide the shari ab rulings (ahkām) by consulting the primary sources of shariah, which are al-Qur'ān and al-Sunnah. Nawäzil (plural form of närilab) is characterised by a set of features surrounding the issue, i.e. occurrence, novelty, significance, and severity. ${ }^{9}$ However, there are fatwa given by local Muslim scholars or mufti on specific topics, e.g. organ and blood donation, which can be linked to particular scenarios in ACTE experimentation. There are a total of 15 fatwa committees in Malaysia ${ }^{10}$ with one at the national level and 14 at the state level (including federal territories). This paper continues to present relevant local fatwa of the issues to give a general understanding concerning the permissibility of using and disposing of samples taken from living human donors in ACTE experimentation.

This paper employed mainly the library research method, a process involves identifying and locating relevant information, analysing main points, which lead to developing and expressing the ideas. ${ }^{11}$ As stated by George (2008), the library research method "involves identifying and locating sources that provide factual information or personal/expert opinion on a research question". ${ }^{12}$ The method may be an essential component of every other research method at a certain time.
Subsequently, the study utilised a common research method used by researchers in various disciplines, including communications, history, and health, which is the textual analysis. The data gathered using this method may come from different instruments, e.g. documents and web pages. ${ }^{13}$

In this study, the primary source that was used to screen and retrieve relevant fatwa was the Department of Islamic Development Malaysia (Jabatan Kemajuan Islam Malaysia) website of Sumber Maklumat al-Ahkām alFiqhiyyah or Source of Information on Islamic Jurisprudence Rulings. As of September 2020, there are 604 proceedings of the Consultative Committee of the National Council for Islamic Religious Affairs Malaysia (Jawatankuasa Muzakarah Majlis Kebangsaan Bagi Hal Ehwal Ugama Islam Malaysia [JMMKI]) and 2,933 states fatwā that are listed on the website. ${ }^{10}$ General online searches and websites of Mufti Department of each state were also examined to complement the search. Tanzil Project webpage (tanzil.net) - Yüsuf 'Alì translation and sunnah.com webpage were referred to, for the English translation of Quranic and Sunnah sources, respectively. Local fatwa related to the sampling of tissue from the human donor was retrieved from the abovementioned sources. The fatwa production, which involves the interpretation of primary sources of Islamic law, was described.

\section{Scenario of Taking Sample from the Living Donor for ACTE Experimentation}

According to the Cambridge Dictionary (proficiency level) ${ }^{14}$, "sample" is defined as "a small amount of a substance that a doctor or scientist collects in order to examine it". Taking samples from the dead human body is related to the term "human biological sample" which is mentioned in the "Malaysian Guidelines on the Use of Human Biological Samples for Research". ${ }^{15}$ The term denotes "all biological material of human origin, including organs, tissues, bodily fluids, teeth, hair and nails; but not established cell lines". In ACTE experimentation, there are various types of tissue harvested from the living human patients or donors to test the ability of the cells to regenerate the articular cartilage. These tissues were obtained from human patients after a medical procedure, e.g. total joint 
replacement. ${ }^{16,17}$ The samples also include various types of stem cells such adipose-derived stem cells ${ }^{18}$, bone marrow mesenchymal stem cells ${ }^{19}$, placenta-derived mesenchymal stem cells ${ }^{20}$, synovium-derived mesenchymal stem cells ${ }^{21}$, tooth germs stem cells ${ }^{22}$, and umbilical cord blood-derived mesenchymal stem cells. ${ }^{23}$ The range of donors' age varied from newborn ${ }^{24}$ to 90 years old. 25

Different from organ or tissue donation for transplantation, the tissues in ACTE experimentation were used for research purposes to investigate and find the cure for joint diseases. However, did the practices violate the shari ${ }^{-}$ah norm? Or, is the donation of human tissues for research purpose in ACTE experimentation permitted in Islam? Below is the presentation of the relevant fatwa related to the cells and tissues sampling from the living donor. The scenario of sampling from the living donor is highly associated with the fatwa of organ donation from living donor for therapeutic reasons. For the stem cells used in research, there is a general fatwa which can be applied directly for ACTE experimentation.

The transplantation is a medical treatment that is not mentioned explicitly in both al-Qur 'an or al-Sunnah because the treatment is yet to be introduced during the prophetic time. However, one of the objectives of the organ transplantation is to save lives, which aligned with the maqūsid al-shari ${ }^{-} a h$. Indeed, the purpose of the tissue donation in ACTE experimentation is not for therapeutic reasons, but as a research application, whereby the result of the experiments will be used as references for the intended clinical purpose.

In general, Penang Fatwā Committee (Jawatankuasa Fatwa Negeri Pulau Pinang) (1st August 2010)26, Johor Fatwā Committee (Jawatankuasa Fatwa Negeri Johor) (2001)27, and Sarawak Fatwa Board (Lembaga Fatwa Negeri Sarawak [JFSarawak]) (1 ${ }^{\text {st }}$ meeting on $8^{\text {th-9 }}$ th $\left.^{\text {December }} 1995\right)^{28}$ reiterated that in non-emergency condition, the organ transplantation is prohibited. The transplantation is only permissible in the state of urgency (therapeutic), and giving an honorarium to the donor in the form of payment is not encouraged to prevent organ procurement for trading purpose.

In $1982, \mathrm{JMMKI}^{29}$ stated the ruling for blood donation was permissible, and there is no need to isolate or segregate Muslim blood with non-muslim blood. However, similar to the organ donation, any kind of honorarium in the form of payment is not advisable. The fatwa is quite general as it did not discuss the requirement of a dire situation as a condition for blood donation:

\section{The Murakarah decided that: 1. The ruling of blood donating is permissible. 2. It is not necessary to separate the blood of Muslims and non-Muslims. 3. An appreciation in the form of money to blood donors is not advisable.}

Meanwhile, the fatwa on tissue graft by JMMKI (1995) ${ }^{30}$ is straightforward as the committee has issued the use of tissue graft as permissible in medical practices, taken that there is no malpractice of trading. However, the purpose of using tissue graft is only for medical or therapeutic purpose. Meanwhile, JFSarawak (meeting no.1/1995 on $8^{\text {th }}-9^{\text {th }}$ December 1995; meeting no.3/1997 on $18^{\text {th }}$ October 1997) 28,31 agreed on the permissibility of the kidney and other organ donation with stipulated terms and conditions including no trading of the organ.

In contrast, in the issue of uterus donation, all three fatwa bodies; JMMKI (106 ${ }^{\text {th }}$ conference on $21^{\text {st }}-22^{\text {nd }}$ October 2014) ${ }^{32}$, JFSarawak (27th meeting on $18^{\text {th }}$ November 2015) ${ }^{33}$, and Sabah Fatwa Council (Majlis Fatwa Negeri Sabah) (conference no.1/2016 on $1^{\text {st }} 3$ rd March 2016) ${ }^{34}$ agreed on its impermissibility. After being briefed by the researchers from Universiti Malaya, JMMKI has concluded that the donation of the uterus is not considered as a necessity (darüriyyah) and only act as a complementary (takmiliyyah) or embellishment (tahsiniyyah) in family life. The uterus donation is also related to hereditary, which may cause doubtful (shubhah) in the lineage. Thus, it can be inferred that the donation of human biological samples for research purposes in ACTE experimentation, obtained from a medical procedure, may be permissible, should the stipulated terms and conditions were observed, and the procedure does not cause any additional harm to the donor, and no trading was involved.

On the other hand, the local fatw $\bar{a}$ bodies derived the consensus and agreed on the permissibility of stem cells 
research based on certain conditions. JMMKI (67th conference on 22nd February 2005) ${ }^{35}$ and Selangor Fatwa Committee (Jawatankuasa Fatwa Negeri Selangor) (JFSelangor) $\left(25^{\text {th }}\right.$ May 2006) ${ }^{36}$, had examined the stem cells issues and adopted the following resolutions with the same ruling or sighah,

It is permissible to obtain, develop and utilise the stem cells for medical treatment or lawful scientific research, if the source is also lawful, such as the following: (1). Adults, if they have given permission and they are not exposed to any harm. (2). Children, if their guardians have given permission for some legitimate reason, and at the same time, these children are not exposed to any harm. (3). Placenta and umbilical cord, if the parents have given permission for that. (4). Miscarried foetus, for some lawful treatment purposes, and with the parents' permission, and not with a foetus that was deliberately aborted without any lawful medical reason. (5). Surplus inoculums from the test-tube babies if available and donated by the parents with their permission. Deliberate inoculation of an ovum and spermatozoa of the female and male donors is not permissible based on the principle of sadd al-dharä $i$.

Apart from that, JMMKI and JFSelangor also had discussed the ruling on therapeutic cloning and stem cell research and come out with the following resolution:

(1) Therapeutic cloning for medical treatment, for instance, to create certain cells or to replace damaged organ is permissible. The act is permitted provided that the shari ${ }^{-1}$ ah precautions are considered. (2) Using frozen embryo or extra embryo in vitro fertilisation process is permissible for research purpose. However, permission must be granted from the married couple who are under treatment. The research on the embryo must be done before the embryo reach the 'alaqah stage (blastocyst). (3) The permission for pre-embryonic research other than therapeutic purposes shall be obtained from the parents. The sample of the research cannot be implanted in the womb of any woman, including the wife. (4) It is permissible to research on preembryos to determine the genetic disease of highrisk parents, and the embryo without disease alone may be implanted in the womb of the mother during the period of legitimate marriage. It is impermissible to conduct any research for commercial purpose or unrelated to maternal or fetal bealth. (5) Genetic engineering treatments on pre-embryos involving the modification of natural buman features such as hair, hair colour, intellectual, height, and so on including gender selection is illegal. However, gender selection is permissible, provided the gender factor may cause a serious genetic disease that can lead to death. 6) The research must be conduct legally, and the proposal must be unambiguous and scientifically sound. The research shall be conducted by professional, skilled, trusted and responsible researchers.

Therefore, it can be concluded that both adult stem cells and embryonic stem cells researches are permissible in Islam as long the shariah precautions are taken considerably. Assessment on the harvesting technique and procedures to gain the cells may be conducted to reduce the harm inflicted on the donors. Thus, the scientists may conduct the research on stem cells, with terms and conditions, to discover further alternatives for cell sources in ACTE experimentation as the issues have been thoroughly addressed and permitted by the fatwo authorities.

\section{Scenario of Discarding Human Tissue in ACTE Experimentation}

As cell sources are coming from the human bodies in ACTE experimentation, then, comes the issue of handling the discarded or used cells and tissues after the sampling or analysis. Even though the procedure for handling the human tissue remnants after the experimentation is not mentioned in detail in ACTE studies, the remnants can be treated as clinical samples for disposal.

The issue of discarding and disposal of patients' tissues has been discussed by Kelantan Fatwā Committee of Council of the Religion of Islam and Malay Custom (Jemaah Ulama' Majlis Agama Islam Dan Adat Istiadat 
Melayu Kelantan) (4th July 2004) $)^{37}$, Islamic Legal Consultative Committee of Pahang (Jawatankuasa Perundingan Hukum Syarak Negeri Pahang) (meeting no. 2/2017 on 27th April 2017) ${ }^{38}$, JFSabah (conference no. 2/2017 on 23rd $24^{\text {th }}$ May 2017) ${ }^{39}$, Negeri Sembilan Fatwā Committee (Jawatankuasa Fatwa Negeri Sembilan) (conference no. 3/2018 on 29th March 2018) ${ }^{40}$, and Islamic Legal Consultative Committee of Federal Territories (Jawatankuasa Perundingan Hukum Syarak
Wilayah Persekutuan [JFWP]) (bayān li al-nās series 170 on $7^{\text {th }}$ March 2019) (11 $^{1}$ with various rulings (by citing the four madhäbib) and șighah. From the given fatwä, it can be highlighted that all the committees advise on the burial of the remnants if there is no danger of spreading disease or health hazard. The present author adopted the ruling of disposing of Muslim body parts and tissue as outlined by the JFWP in the following Table 1:

Table 1: Method of discarding human body parts and tissues based on particular situations.

\begin{tabular}{lll}
\hline Situation & Discarding Method \\
\hline 1. & $\begin{array}{l}\text { Handling and disposal } \\
\text { of Muslim body parts } \\
\text { and tissues }\end{array}$ & $\begin{array}{l}\text { B. According to the majority of jurists, any body parts that are cut off from the living body, } \\
\text { including nail or hair, need to be buried without being washed and prayed for. }\end{array}$
\end{tabular}

Body parts and tissues of deceased Muslim

i. According to al-Hanafi and al-Mäliki si schools, if a large part of the corpse were to be found, it must be bathed, shrouded, prayed for, and buried.

ii. For al-Shäfi $i$ i and al-Hanbali sects, the deceased must be bathed, shrouded, prayed for, and buried even only a small part of the corpse is found.

2. Handling and disposal of non-muslim body

It should be buried or cremated according to the religious teachings of the deceased.

3. Handling of body parts and tissues which are a health hazard and may contaminate the environment

i. The organs and tissues removed and cut off from the patient's body, either Muslim or nonmuslim patients should be buried.

ii. If the organs or tissues are contaminated with infectious diseases, then the hospital should decontaminate them with certain chemicals before burying them.

iii. If there are no other alternatives to decontaminate the organs and tissues, it is permissible to incinerate them based on the principle of darüriyyah .

4. Handling of Muslim fetus

5. Existing regulation of handling and disposal

\section{a. The fetus survived for a moment when it was born}

i. If it lived for a short while after being born, it should be given a name, bathed, and prayed for. It also has the right to inherit and to be inherited of its property based on the relevant fiqh just the same as the other living person.

ii. In al-Shäfi $i$ sect, if the baby was crying during birth delivery and it was certain, it was being alive by signs of life (there was a movement etc.), then it is required for the baby to be bathed, shrouded, prayed for, and buried just like adult's funeral.

\section{b. The fetus died at birth (stillbirth)}

i. According to al-Hanafi sect, if the fetus is stillborn, and there is no sign of life, it must be bathed, named, shrouded in a piece of cloth, and buried without prayer.

ii. For al-Mälikè sect, a stillborn baby without any signs of life such as crying (baby's movements are not considered as a sign of life), it is not necessary to bathe the deceased. According to $I b n$ Shibäb, the stillborn baby need not be prayed for, but it can be buried with its deceased mother.

iii. If the baby was not crying during the labour and the age is not up to four months, then it is not an obligation for it to be bathed, shrouded, and prayed for. However, it is recommended (mandüb or mustahabb) for the baby to be shrouded and buried without being prayed for.

iv. In al-Hanbali school, as mentioned by Ibn Qudamah, if the fetus had reached the age of four months or had a perfect body form, thus it should be bathed and prayed for although there are no signs of life and it is recommended to give a name to it.

i. Based on the current practice, the concessionaire will dispose of the chemical and clinical waste, including human tissues, organs, and fetuses through incineration.

ii. Under the proposal to bury chemical waste containing formalin and other chemicals, the Ministry of Health Malaysia has discussed the matter with the Department of Environment. The department suggested that the materials should be buried in an area with 100 meters away from the water source. Also, it is recommended that the burial site to be adjacent to the existing graves as long as it is away from water sources, residential areas, wells and dams. 
At the moment, as highlighted by JFWP41, the current practice of Malaysian hospitals is that the disposal of the "clinical waste" is done by incineration which handled by concession companies (Radicare Sdn. Bhd., Faber Medi-Serve Sdn. Bhd., and Pantai Medivest Sdn. Bhd.) which is responsible for the disposal of the hospitalisation process at the hospital premises to the incineration process. While the disposal of "chemical waste" is done by the Concession Company Quality Nature Sdn. Bhd. JFWP41 concluded that the current practice of "clinical waste" disposal is not considered in line with the shariah unless there is an urgency to do so. The practice may also be applied in the case of ACTE experimentation whereby the concession company will collect the clinical waste to be discarded. Thus, the researchers need to improve the standard operating procedure in discarding the clinical waste in ACTE research to be in line with shari ${ }^{-} a h$.

\section{CONCLUSION}

In searching for the treatment for degenerative joint diseases, the researchers of ACTE have been utilising human tissues as the cell sources. The tissues were sampled from the living donor from different parts of the body, and various types of cells were harvested. Due to this method of using human samples are widely accepted in ACTE experimentation, there is a need to screen the practices from an Islamic perspective, through the analysis of relevant fatwa . Verily, the experiments are essential to developing a new treatment in the tissue engineering field to produce functional articular cartilage tissue. However, it is far more important for the researchers to ensure their conduct to be in line with the shari ${ }^{-1} a h$. ACTE researchers are advised to refer to the fatwa committees or religious bodies before adopting or adapting the international biomedical practices, before implementing the technology in Muslim societies, i.e. Malaysia. The fatwa can be used as references for the researchers in conducting their studies, to be in line with shari ${ }^{-1} a$. In conclusion, ACTE researchers may utilise the biological samples from living donors as alternatives in studying articular cartilage regeneration. The donation of human biological samples for research purposes in ACTE experimentation, obtained from a medical procedure, may be permissible, should the stipulated terms and conditions were observed, and the procedure does not cause any additional harm to the donor. Besides, the current standard operating procedure of discarding the clinical waste in ACTE research needs to be improved, so that, the procedure to be in line with shari ${ }^{-1} a h$. Despite new efforts to align researches in ACTE with the shariah, further study needs to be done to develop a permissible (haläl) environment of ACTE experimentation.

\section{CONFLICT OF INTEREST}

The authors in this study declare that there is no conflict of interest.

\section{ACKNOWLEDGEMENT}

The authors thanked International Islamic University Malaysia (IIUM) and expressed their gratitude to the Ministry of Higher Education for their support and for providing the Transdisciplinary Grant Scheme (TRGS/1/2016/UIAM/02/8 - TRGS16-02-003-0003).

\section{REFERENCES}

1. Liu P. Muslim struggle to determine if a device is halal seen as opportunity. Halal Focus. 2015.

2. Zarmani NF, Ramli MA, Salleh SMSSM. The ethical aspects of halal certification of medical devices in Malaysia. In: 15th Asian Bioethics Conference (ABC 15) \& 12th Asia Pacific Conference (APC 12) [Internet]. p. 303-6. Available from: http://www.apu.ac.jp/rcaps/ uploads/fckeditor/ Conference/2014APConferencePictures / Proceedings-2.pdf\#page $=301$

3. Shah H, Yusof F. Gelatin as an ingredient in food and pharmaceutical products: An islamic perspective. Adv Environ Biol. 2014;8(3 SPEC. ISSUE):774-80.

4. MIHAS. Halal Pharmaceuticals: A New Frontier. 2018.

5. Ahmad Radzi MA, Mohd. Azharuddin NS, Hashi AA, Azhim A, Sha'ban M. A Survey on Relevant Malaysian Fatwā about Cadaver Concerning Tissue Engineering Research. Pertanika J Soc Sci Humanit [Internet]. 2020;28(2):1451-66. Available from: 
http://www.pertanika.upm.edu.my/Pertanika PAPERS/JSSH Vol. 28 (2) Jun. 2020/42 JSSH5566-2019.pdf

6. Trommelmans L, Joseph S, Kris D. Ethical Issues In Tissue Engineering. 2007.

7. Muhammad Aa'zamuddin AR, Hashi AA, Sha'ban M. An overview of the application of Maqasid AlShariah into cartilage tissue engineering. Int Med J Malaysia. 2018;17(Special Issue 1):151-6.

8. Rozlin AR, Muhammad Aa'zamuddin AR, Norhamiza MS, Noorhidayah MN, Munirah S. Tissue engineering of articular cartilage: From bench to bed-side. Tissue Eng Regen Med [Internet]. 2015;12(1):1-11. Available from: http:// link.springer.com/10.1007/s13770-014-9044-8

9. Majd. Fiqh al-Nawazil [Internet]. Financial Encyclopedia. Investment and Finance; 2015 [cited 2019 May 15]. Available from: https:// www.investment-and-finance.net/islamic-finance/f/ fiqh-al-nawazil.html

10. Jabatan Kemajuan Islam Malaysia. Institusi/ Organisasi [Internet]. Sumber Maklumat al-Ahkam al-Fiqhiyyah. [cited 2019 Jun 19]. Available from: http://e-smaf.islam.gov.my/e-smaf/index.php/ main/mainv1/maklumat_fatwa/2

11. Elmer E. Rasmuson Library. Library Research Process [Internet]. 2018 [cited 2020 Mar 2]. Available from: https://library.uaf.edu/ls101research-process

12. George MW. The Elements of Library Research. New Jersey: Princeton University Press,; 2008.

13. Smith JA. Textual Analysis. In: The International Encyclopedia of Communication Research Methods. John Wiley \& Sons, Inc.; 2017.

14. Cambridge Dictionary. Sample [Internet]. [cited 2019 Oct 9]. Available from: https:// dictionary.cambridge.org/dictionary/english/sample

15. National Committee for Clinical Research. Malaysian Guidelines on the Use of Human Biological Samples for Research [Internet]. 2nd ed. Clinical Research Malaysia. Kuala Lumpur: Clinical Research Malaysia; 2015. Available from: www.clinicalresearch.my

16. Zhang W, Chen J, Tao J, Hu C, Chen L, Zhao H, et al. The promotion of osteochondral repair by combined intra-articular injection of parathyroid hormone-related protein and implantation of a bilayer collagen-silk scaffold. Biomaterials [Internet].
2013;34(25):6046-57. Available from: http:/ / dx.doi.org/10.1016/j.biomaterials.2013.04.055

17. Iwata K, Asawa Y, Fujihara Y, Tanaka Y, Nishizawa S, Nakagawa T, et al. The Effects of Rapid- or Intermediate-Acting Insulin on the Proliferation and Differentiation of Cultured Chondrocytes. Curr Aging Sci. 2012;3(1):26-33.

18. Xiao BJ, Yong SS, Zhang K, Wang J, Tai PS, Xiao DJ, et al. Tissue engineered cartilage from hTGF $\beta 2$ transduced human adipose derived stem cells seeded in PLGA/alginate compound in vitro and in vivo. J Biomed Mater Res - Part A. 2008;86(4):1077 -87 .

19. Tamaddon M, Burrows M, Ferreira SA, Dazzi F, Apperley JF, Bradshaw A, et al. Monomeric, porous type II collagen scaffolds promote chondrogenic differentiation of human bone marrow mesenchymal stem cells in vitro. Sci Rep [Internet]. 2017;7(January):1-10. Available from: http:/ / dx.doi.org/10.1038/srep43519

20. Li F, Chen Y-Z, Miao Z-N, Zheng S, Jin J. Human Placenta-Derived Mesenchymal Stem Cells with Silk Fibroin Biomaterial in the Repair of Articular Cartilage Defects. Cell Reprogram. 2018;14(4):334 41.

21. Koizumi K, Ebina K, Hart DA, Hirao M, Noguchi T, Sugita N, et al. Synovial mesenchymal stem cells from osteo- or rheumatoid arthritis joints exhibit good potential for cartilage repair using a scaffoldfree tissue engineering approach. Osteoarthr Cartil [Internet]. 2016;24(8):1413-22. Available from: http://dx.doi.org/10.1016/j.joca.2016.03.006

22. Svobodová J, Proks V, Karabiyik Ö, Çalıkoğlu Koyuncu AC, Torun Köse G, Rypáček F, et al. Poly(amino acid)-based fibrous scaffolds modified with surface-pendant peptides for cartilage tissue engineering. J Tissue Eng Regen Med [Internet]. 2017 Mar;11(3):831-42. Available from: http:/ / doi.wiley.com/10.1002/term.1982

23. Kim IG, Ko J, Lee HR, Do SH, Park K. Mesenchymal cells condensation-inducible mesh scaffolds for cartilage tissue engineering [Internet]. Vol. 85, Biomaterials. Elsevier Ltd; 2016. 18-29 p. Available from: http://dx.doi.org/10.1016/ j.biomaterials.2016.01.048

24. Zhang X, Mitsuru A, Igura K, Takahashi K, Ichinose S, Yamaguchi S, et al. Mesenchymal progenitor cells derived from chorionic villi of 
human placenta for cartilage tissue engineering.

Biochem Biophys Res Commun [Internet]. 2006 Feb;340(3):944-52. Available from: https:// linkinghub.elsevier.com/retrieve/pii/ S0006291X05028421

25. Kafienah W, Mistry S, Dickinson SC, Sims TJ, Learmonth I, Hollander AP. Three-dimensional cartilage tissue engineering using adult stem cells from osteoarthritis patients. Arthritis Rheum. 2007;56(1):177-87.

26. Jawatankuasa Fatwa Negeri Pulau Pinang. Transplan Organ Dan Tisu. In 2010. Available from: http://mufti.penang.gov.my/ index.php/2014-11-12-02-48-39/fatwa/warta/391hukum-transplan-organ-dan-tisu-9-disember-2010/ file

27. Jawatankuasa Fatwa Negeri Johor. Hukum Transplan Organ Dan Mati Otak. In 2001. Available from: http:/ / e-smaf.islam.gov.my/esmaf/index.php/main/mainv1/fatwa/pr/10621

28. Lembaga Fatwa Negeri Sarawak. Pemindahan Organ. In 1995. Available from: http://esmaf.islam.gov.my/e-smaf/fatwa/fatwa/find/ $\mathrm{pr} / 11445$

29. Jawatankuasa Fatwa Majlis Kebangsaan Bagi Hal Ehwal Ugama Islam Malaysia. Derma Darah Dan Penggunaan Darah Orang Islam Kepada Orang Bukan Islam Dan Sebaliknya (1982). In: Kompilasi Pandangan Hukum Muzakarah Jawatankuasa Fatwa Majlis Kebangsaan Bagi Hal Ehwal Ugama Islam Malaysia [Internet]. Jabatan Kemajuan Islam Malaysia; 1982. p. 102. Available from: http:// www.islam.gov.my/images/ePenerbitan/ KOMPILASI_MUZAKARAH_MKI_2016.pdf

30. Jawatankuasa Fatwa Majlis Kebangsaan Bagi Hal Ehwal Ugama Islam Malaysia. Penggunaan Graf Tisu Dalam Amalan Perubatan. In 1995. Available from: http:/ / e-smaf.islam.gov.my/e-smaf/ index.php/main/mainv1/fatwa/pr/15241

31. Lembaga Fatwa Negeri Sarawak. Pendermaan Ginjal. In 1997. Available from: http://esmaf.islam.gov.my/e-smaf/index.php/main/ mainv1/fatwa/pr/11431

32. Jawatankuasa Fatwa Majlis Kebangsaan Bagi Hal Ehwal Ugama Islam Malaysia. Hukum Pendermaan Rahim. In 2014. Available from: http://esmaf.islam.gov.my/e-smaf/index.php/main/ mainv1/fatwa/pr/10318
33. Lembaga Fatwa Negeri Sarawak. Pendermaan Dan Pemindahan Rahim. In 2015. Available from: http:/ /e-smaf.islam.gov.my/e-smaf/fatwa/fatwa/ find/pr/15419

34. Jawatankuasa Majlis Fatwa Negeri Sabah. Pendermaan Rahim. In 2016 [cited 2019 Apr 16]. Available from: http:/ / e-smaf.islam.gov.my/esmaf/fatwa/fatwa/find/pr/15408

35. Jawatankuasa Fatwa Majlis Kebangsaan Bagi Hal Ehwal Ugama Islam Malaysia. Hukum Pengklonan Terapeutik Dan Penyelidikan Sel Stem. In: Kompilasi Pandangan Hukum Muzakarah Jawatankuasa Fatwa Majlis Kebangsaan Bagi Hal Ehwal Ugama Islam Malaysia [Internet]. Shah Alam, Selangor, Malaysia: Jabatan Kemajuan Islam Malaysia; 2005. p. 112. Available from: http:// www.islam.gov.my/images/ePenerbitan/ KOMPILASI_MUZAKARAH_MKI_2016.pdf

36. Jawatankuasa Fatwa Negeri Selangor. Hukum pengklonan terapeutik dan penyelidikan sel stem (stem cell). In Government of Selangor Gazette; 2006. Available from: http:// www.muftiselangor.gov.my/fatwa-personalisation/ fatwa-tahunan/pewartaan/2005-2009/165-hukumpengklonan-terapeutik-dan-penyelidikan-sel-stemstem-cell

37. Jemaah Ulama' Majlis Agama Islam dan Adat Istiadat Melayu Kelantan. Pembuangan Dan Pelupusan Tisu-Tisu Manusia Daripada Pesakit. In 2004. Available from: http:// www.epusara.jawi.gov.my/epusara/webV5/ content/154

38. Jawatankuasa Perundingan Hukum Syarak Negeri Pahang. Pelupusan Anggota, Tisu, Dan Janin Orang Islam. In 2017. Available from: http:// mufti.pahang.gov.my/index.php/perkhidmatan/ bahagian-fatwa/keputusan-fatwa/31-keputusanfatwa-2017/136-hukum-pelupusan-anggota-tisudan-janin-orang-islam

39. Jawatankuasa Majlis Fatwa Negeri Sabah. Pelupusan Anggota, Tisu Dan Janin Orang Islam. In 2017. Available from: http://esmaf.islam.gov.my/e-smaf/index.php/main/ mainv1/fatwa/pr/15444

40. Jawatankuasa Fatwa Negeri Sembilan. Pelupusan Anggota, Tisu Dan Janin Orang Islam. In 2018. Available from: http://www.muftins.gov.my/ index.php/arkib2/himpunan-fatwa/171-keputusan 
-mesyuarat-fatwa/1005-hukum-pelupusan-anggotatisu-dan-janin-orang-islam

41. Jabatan Mufti Wilayah Persekutuan. Bayan Linnas Siri ke-170: Anggota, Tisu dan Janin Orang Islam: Hukum Pelupusannya [nternet]. 2019 [cited 2019 Jun 6]. Available from: https://muftiwp.gov.my/ en/artikel/bayan-linnas/3180-bayan-linnas-siri-ke170-anggota-tisu-dan-janin-orang-islam-hukumpelupusannya 